of power over the right half of the body was noticed, and the headache and intolerance of light were persistent. $\mathrm{He}$ gradually became worse. Breathing was difficult, and the pulse weak and frequent. He conld hardly answer questions put to him. He ultimately hecame unconscious, passing urine under him, and died on Oct. l3th.

On making a post-mortem examination, the following appearances were noticed. The dura mater was not adherent. The portion covering the left frontal lobe appeared to be thrown into folds, having no firm support underneath it. On cutting it and pushing the left half aside, a large quantity of thick purulent matter of tire consistence of clarified butter was found lying over the left frontal lobe, which appeared to be depressed in the centre, with the convolutions flattened out, and having a white, smooth mark on its surface. Pus was also found underneath it and the middle lobe. On removing the brain and the purulent matter, thrombosis of the left cavernous sinus was found, containing an ante-mortem clot. There was no disease of bone. The brain substance was normal, and there was no effusion or hiemorrhage in the ven tricles or its substance; it weighed $460 z$. There was no disease of the ear on the left side. The liver and kidneys were normal; so was the spleen. There was congestion of the right lung at its base; the left lung was normal. The heart weighed $7 \frac{1}{3} \mathrm{oz}$, and contained a defibrinated clot in its right cavity; its walls and valves were normal.

Remarks.-It was difficult to account for the presence of pus confined to the anterior portion of the brain. Apparently it had no connexion either with the brain substance or its membranes. Was the thrombosis of the sinus due to bronchitis, and the formation of pus the result of thrombosis, leading toleakage of serum, which subsequently changed intopus? Pishin.

\section{ACETANILIIDE (ANTIFEBRIN) AS AN EXTERNAL APPLICATION.}

BY A. H. NeWTH, M.D.

I HAVE not noticed any reference to antifebrin as a local sedative or antipyretic, and am unaware of its having been used as such. It occurred to me to try the effects of it in this way, and the remarkable results in the few cases in which $\mathrm{I}$ have prescribed it leads me to anticipate that a more extended use of this remedy as an external application will be found of great value. Country practice, especially such a healthy district as this is, does not afford much scope for experience in skin diseases, and I have only tried it for a few months. My usual plan is to prescribe it with lanoline or vaseline in the proportion of twenty grains to the ounce, combined with other ingredients that seem applicable to special cases. In obstinate irritalle ulcers it soothes the pain and subdues the inflammation. In psoriasis, combined with some mercurial preparation, it acts like a charm. I have also tried it in erythema, erysipelas, eczema, herpes, urticaria, and other complaints associated with considerable irritation, and have found it a most useful adjunct to suitable remedies.

Hayward's Heath.

\section{ECZEMA CAUSED BY IODOFORM.}

By H. Campbel. Pope, M.D. Lond., F.R.C.S.

U[Ps. W- suffered from an inflamed bursa near the elbow.joint, which was opened antiseptically and dressed with iodoform gauze. A violent attack of eczema ensued, spreading over the whole of the limb. The eczema was cured by oleate of zinc ointment. The bursa, having filled a second time some months afterwards, was opened and dressed as before, with a like result-namely, an attack of eczena. On discontinuing the iodoform gauze and dressing with oleate of zinc ointment, the attack soon passed off. On a third vecasion, before the wound had thoroughly healed, the scab was accidentally removed. Iodoform ointment was inadvertently prescribed, and eczema appeared for the third time. It would seem in this case that iodoform was the exciting cause on each occasion of the eczema.

Shepherd's Bush.

\section{A a ditrror}

OF

\section{HOSPITAL PRACTICE, BRITISH AND FOREIGN.}

Nulla autem est alia pro certo noscendi via, nisi quamplurimas et morborum et dissectionum historias, tum aliorum tum proprias collectas habere, et inter se comparare.-MorgagnI De Sed. et Caus. Mort. lib. iv. Procemium.

\section{LONDON HOSPITAL.}

SURGICAL CASES NOW IN THE WARDS.

(Under the care of Mr. Treves.)

Tre cases to which we draw attention this week are still in the wards under the care of Mr. Treves; it is true that the disease in each instance has been removed, but as the morbid product is preserved, and can also be shown, the cases are practically complete and worth seeing. Tumours of the muscles are of considerable rarity as primary growths, and the sarcomata very liable to recur. Teevan suggested that the entire muscle, from its origin to its insertion, should be removed; it has, however, seldom been possible to do this. The operation which Mr. Treves performed was a bold and extensive one; but by it the whole of the discase was removed, the tough sheath of the rectus having prevented its lateral extension, whilst the peritoneum bounded it beneatl. The application of a temporary ligature to one of the main arteries of the body, used simply to control hæmorrhage during operation, the loop being left in position ready for use in case of recurrent hæmorrhage, was a measure which diminished considerably the risks of the operation and facilitated its performance. There was no injury inflicted on the artery by its compression, which could hardly have been successfully carried out by any other means. In another ward may be seen the subject of Case 3 , an example of a rare disease in an unusual sitnation. The cyst in Case 4 suggested to Mr. Treves the possibility of its development in consequence of the carrying into the wound of a portion of the skin and its growth in a new situation. The only objection against this view of its origin was the distance of the wound from the site of the twnom.

CAsE 1. Removrl of the Rectus Abdominis for Sarcome.A married woman aged twenty-four was admittel into Dr. Stephen Mackenzie's wards on March 3rd, 1889, and was transferred to Mr. Treves' care on March 18th. She was suffering from a tumour in the anterior abdominal wall. There was nothing in the patient's family history that was noteworthy, and she herself had always been-particularly robust. She had had three children, all living. The last child was born on Dec. 3rd, 1858. In the previous August (she being then about six months preonant) she observed a small lump just to the right of the umbilicus. It was about the size of a small hen's egg, was hard, movable, and deep beneath the skin. It was a little tender, but she attached no importance to it. During the remaining months of her pregnancy she believed that the tumour scarcely grew at all. When she examined it after her confinement it was decidedly larger, and since the birth of the child its growth had been very rapid. She could recall no injury to the abdomen, and no muscular sprain. Her confinement was uncomplicated and her recovery rapic.

The patient was robust and well nourished when admitted into the hospital. She had gained flesh since her confinement, and there was no anæmia. Nothing abnormal could be detected in any of her viscera. She appeared, indeed, in quite sound health, and was troubled only by the rapid growth of the tumour. The abdominal wall was still flaccid, and the skin over it loose and easily drawn into folds. The muscles had evidently not recovered from the distension of pregnancy. An oblong tumour occupied the richt rectus muscle, and was clearly within its sheath. It measured eight inches in length and nearly five in breadth. Its centre was opposite to the umbilicus, and about this level was a transverse furrow cressing the growth and produced by the lowest tendinons intersection. The patient was of short stature, and the mass conseruently occupied nearly the whole of the fleshy part of the muscle. 'The 